\title{
Factors Influencing the Intention to Purchase Real Estate in Saudi Arabia: Moderating Effect of Demographic Citizenship
}

\author{
Tawfik Salah AL-Nahdi ${ }^{1}$, Shakeel A. Habib ${ }^{2} \&$ Ali Abbaas Albdour ${ }^{3}$ \\ ${ }^{1}$ Faculty Member, Prince Sultan College for Business, Al-Fisal University, Saudi Arabia \\ ${ }^{2}$ Prince Sultan College for Business, Al-Fisal University, Saudi Arabia \\ ${ }^{3}$ College of Business and Administration, Princess Nora Bint Abdul Rahman University, Riyadh, Saudi Arabia \\ Correspondence: Tawfik Salah AL-Nahdi, Prince Sultan College for Business, Al-Faisal University, Jeddah, \\ Saudi Arabia. E-mail: t.alnahdi@pscj.edu.sa
}

Received: December 17, 2014

Accepted: February 12, 2015

Online Published: March 27, 2015

doi:10.5539/ijbm.v10n4p35

URL: http://dx.doi.org/10.5539/ijbm.v10n4p35

\begin{abstract}
Factors affecting the real estate market are of great importance worldwide. This study will investigate the factors influencing Saudis to purchase real estate. The study examine the effect of attitude, subjective norm, perceived behavior control and demographics on the intention to purchase real estate. Taking into account that demographics (Citizenship) as a moderator, a total of 450 questionnaires were distributed to respondents in Jeddah. Based on 322 questionnaires collected, the results show that there is a positive significant relationship between Attitude, and Subjective Norm toward the intention to purchase real estate, while the Perceived Behavior Control has not. demographic (Citizenship) were found not to have a moderating effect on the relationship between independents and the customers' intention to purchase real estate among Saudis.
\end{abstract}

Keywords: behavioral real estate, consumer behavior, demographics, jeddah, saudi arabia, theory of planned behavior

\section{Introduction}

The focus is on Saudi Arabia real estate market for a number of reasons. Firstly, Saudi Arabia is a pivotal country with the largest real estate market in the oil-rich Gulf. In addition, secondly, around $45 \%$ of the population is below age 20 years. This and the rapid urbanization rate combined to increase the growth which already happening at real estate market (Opoku \& Abdul-Muhmin, 2010). In Saudi Arabia, discovery of oil in commercial quantities in the late 1930s besides the increasing of oil prices during the 1970s, shifted traditional Saudi society to lifestyles of developed societies (Mubarak, 1995). Prior to 1970, the largest segment of the population was rural. Since 1970, the population of Saudi Arabia has boomed dramatically and experienced a new trend, that is, the shift of the population from rural to urban areas (Al-Hathloul, 1995). Especially the major urban centers witnessed unmatched growth (Mubarak, 1995). Between 1950 and 1992, the level of urbanization in Saudi Arabia increased parallel with tremendous growth for the population for the same period. For example, the rate of population that live in urban areas increased from 10\% to 77\% (Al-Hathloul, 1995; Mubarak, 1995). Economic improvement for government and citizens resulted in jump in urban development characterizing Jeddah and many other major Saudi cities (Mubarak, 1995). Alotaibi (2006), Jeddah represents one of the largest urban areas in Saudi Arabia. Jeddah's urban population has grown rapidly from 1970 to 2002 to an estimated population of 2,560,000 with annual growth rates of $12.43 \%$ in 1970 and a rate of $11.05 \%$ in 2000 . According to Alotaibi (2006), from 1977 to 2002, the rate of ownership has dramatically increased from $19 \%$ to $35 \%$. And for the same period, there is a decrease in the rate of renters, from, $77 \%$ to $58 \%$, between 1977 and 2002 . As a consequence of Jeddah being the main economic city, it has provided more jobs and high income result with improved opportunities for a better quality of life. All reports on the Saudi real estate market reported there was a high demand on real estate units mainly in the residential sector that will require huge number of units, with almost 1 million units by 2012 (Opoku \& Abdul-Muhmin, 2010). Understanding the factors influencing consumers behavior to purchase real estate in Saudi market is important. This will provide crucial insight for decision makers and policy developers in managing the housing demand. According to earlier studies (Gibler \& Nelson, 2003; Opoku \& Abdul-Muhmin, 2010) this kind of studies may provide results that will also be of importance for real estate developers to satisfy the needs and wants of their customers (Gibler \& Nelson, 2003; 
Opoku \& Abdul-Muhmin, 2010).

\section{Literature Review}

Formal involvement in housing in Saudi Arabia started in 1951. The Saudi government used funding to provide housing for I tscitizens. The government fund called the Real Estate Development Fund (REDF) offers cash loans of up to SR500, 000 (US 133,000), repaid in installments for 25 years to citizens and with zero interest, to construct or buy their own houses. The only two requirements for REDF is that a Saudi citizen must be at least 21 years old and he/she did not receive a previous REDF loan without any restrictions to area. REDF has no conditions for location. According to Mubarak, 1995; Susilawati \& Anunu, 2001; Alotaibi, 2006, and the Centre for Housing Research, (2008), housing development in Jeddah has changed over the last 50 years. A household's dream for property is highly related to housing choices which take into account changes in social and economic factors that affect Jeddah's housing, must be taken into account in any analysis of the housing market in Jeddah. The housing sector needs to identify these key trends and assess their implications for the housing market. A housing neighborhood and its location in relation to services are important in housing markets. Weak regulations in some areas brought problems in some area like streets capacity, infrastructure, utilization of common facilities and social services which resulted in discomfort to many residents of several units. Demand for housing increased from the seventies of the past century until now. Developers need to know some factors which influenced o the decision making process of purchasing a house. In order to develop the most suitable marketing plan. According to Al Hathloul and Edadan (1995) "the economic contribution of the real estate construction sector during the last twenty years has been very significant. The value-added share of the construction sector had increased from $3.2 \%$ to $13.4 \%$, registering an annual compound growth rate of $11.2 \%$. During five years, the real estate sector's contribution to the GDP increased from $2.9 \%$ to $3.7 \%$. From 2003 until now, most developed countries are having boom in the housing demand despite there being an increase in residential houses investment.

In order to win the market competition, some factors which influence the decision making process of purchasing real estate need to be determined. Therefore, the purpose of this research is to study Saudi consumer intention to purchase real estate. The attitude, subjective norm and perceived behavioral control of the Saudi consumer, and the demographics of housing purchaser's toward the intention to purchase real estate, will be studied in a sample of consumers.

\subsection{Theory of Reasoned Action (TRA)}

TRA is a general theory to explain general human behaviour. Fishbein and Ajzen's (1975) have developed theoretical grounds of theory of reasoned action (TRA) which states that beliefs influence attitudes, which lead to intentions, and finally to behaviours. TRA was derived from previous research that started out as the theory of attitude. It has, however, led to the study of attitude and behavior. The components of TRA consists three general constructs: behavioral intention, attitude, and subjective norm. TRA suggests that a person's behavioral intention depends on the person's attitude towards the behavior and subjective norm (Ramayah \& Suki, 2006).

\subsection{Theory of Planned Behavior (TPB)}

Theory of Planned Behavior (TPB) as proposed by Ajzen (1991) is an extension of the Theory of Reasoned Action (Ajzen \& Fishbein, 1980) to predict behavior in real-world mode. During the past decades TPB has been used by many researchers, and it showed it was able to predict intentions. A person's behavior intention is influenced by an attitude toward the behavior, subjective norms and perceived behavior control (Ajzen, 1991). According to Ajzen (1991), the Theory of Planned Behavior (TPB) is used to understand the relationship of intentions to performing a behavior. These intentions are influenced by attitudes towards the behavior, the social pressure to perform this behavior, which is known as subjective norms, and control over the behavior, which is referred to as behavioural control (Ajzen, 1991). TPB was accepted as a theory to explain and forecast human behavior (Numraktrakul et al., 2012). TPB has been used to investigate the factors influencing consumers to purchase their residential units (Phungwong, 2010; Si, 2012). The Theory of planned behavior is a suitable model to study the factors influencing home purchase intentions (Phungwong, 2010; Numraktrakul et al., 2012).

\subsubsection{Attitude}

Attitude is the person's favor or disfavor toward an action (Tonglet et al., 2004, Al-Nahdi et al., 2008; Al-Nahdi et al., 2009). Attitude is defined as a psychological tendency that is expressed by evaluating a particular entity with some degree of favor or disfavor (Ajzen \& Fishbein, 1980). Attitude is also defined as the way individuals respond to and are disposed towards, an object (Yusliza \& Ramayah, 2011).

Previous studies (Davis et al., 1989; Cronin \& Taylor, 1992; French et al., 2005; Gopi \& Ramayah, 2007; Han \& 
Kim, 2010; Ing-Long \& Jian-Liang, 2005; Jackson et al., 2003; Kim \& Han, 2010; Ramayah et al., 2008) found that there is a strong and steady relationship between attitude and repurchase intention. Customers have the intention to compare the perceived service with the expected service. If customers felt that the service is below their expectation, they would be dissatisfied. However, if customers' feelings were equal to or exceeds their own expectations, they will be satisfied. Accordingly, they intended to purchase from the provider (Kotler \& Keller, 2006). The role of feelings of the purchaser influence purchasing process of a custom-made prefabricated house (Koklič \& Vida, 2009). A person who has beliefs that result from engaging in a positive behavior will have a positive attitude toward performing the behavior, while a person who has beliefs that result from engaging in a negative behavior will have a negative attitude toward performing the behavior (Ajzen, 1991). Attitudes is one of the determinants that affect individual behavior (Gibler \& Nelson, 1998). Attitude influences consumer intention to purchase durables (Chung \& Pysachik, 2000; Summers et al., 2001) Attitude influences consumer intention to purchase a house (Phungwong, 2010; Numraktrakul et al., 2012).

\subsubsection{Subjective Norm}

Subjective Norm results from how the person perceives the pressures placed on him/her to perform or not to perform the behavior (Ajzen, 1991; Tonglet et al., 2004; Han \& Kim, 2010; Kim \& Han, 2010). Consumers' perception of social pressures put on him by others to purchase a product (Phungwong, 2010). Friends, parents, political parties, and/or agent might be involved in the purchasing decision (Kalafatis et al., 1999). The attitude of others influences the purchase intention and purchase decision. Attitude of others means to which limit the attitude of others affect the customer's purchase decision and of choosing a particular product among different products. When others are close to a customer and have high negativism toward the product, customers will be more likely to adjust his purchase intention. And a customer's purchase intention will increase if others have others preferences to the same product (Ajzan \& Fishbein 1980; Kotler \& Keller, 2006; Rivis \& Sheeran, 2003). Previous studies showed different results regarding the subjective norm as a predictor of intention. There are some studies that showed a significant relationship between subjective norm and intention (Taylor \& Todd, 1995; Venkatesh \& Davis, 2000; Ramayah et al., 2003, 2004; Chan \& Lu, 2004; Baker et al., 2007; Teo \& Lee, 2010). Other some studies, again, showed there is no significant relationship between subjective norm and intention (Davis et al., 1989; Mathieson, 1991; Chau \& Hu, 2001; Lewis et al., 2003). Latest studies found that subjective was a predictor of intention at different areas (Alam \& Sayuti, 2011; Gupta \& Ogden, 2009; Han \& Kim, 2010; Iakovleva et al., 2011; Kim \& Han, 2010; Wu et al., 2011). Koklič and Vida (2009) External factors of the purchaser also influence the purchasing process of a custom-made prefabricated house. External factors like reference groups and family purchaser influence purchasing process of a custom-made prefabricated house (Koklič \& Vida, 2009). Susilawati et al. (2001) found friends colleagues and wives have influenced the decision making of purchasing a house by $45 \%$. Social and cultural factors play a significant role in the relative importance of housing preferences which are determined by religion, kinship, and social relations (Jabareen, 2005). Consumers are sometimes influenced by friends' information involved with the actual home decision (Kichen \& Roche, 1990). Social factors play significant roles in choosing a house to purchase (Al-Momani, 2000). Subjective norms influence a consumer intention to purchase a house (Phungwong, 2010; Numraktrakul et al., 2012).

\subsubsection{Perceived Behavioral Control}

Perceived behavior control is defined as the extent to which the person has control over internal and external factors that facilitate or constrain the behavior performance. Control beliefs are a person's beliefs toward factors available which facilitate or prevent performing a behavior (Ajzen, 2001; Han \& Kim, 2010; Kim \& Han, 2010; Tonglet et al., 2004). Latest studies found that perceived behavioral control was a predictor of intention (Iakovleva et al., 2011; Wu et al., 2011; Alam \& Sayuti, 2011). Various research in various areas, showed that there is a positive relationship between perceived behavioral control and intention (Blanchard et al., 2008; Fang, 2006; Gopi \& Ramayah, 2007; Ing-Long \& Jian-Liang, 2005; Jen-Ruei et al., 2006; Mathieson, 1991; Ramayah et al., 2008; Shih \& Fang, 2004; Taylor \& Todd, 1995; Teo \& Pok, 2003; Wise et al., 2006; Baker et al., 2007; Teo \& Lee, 2010). In the real estate area researchers found perceived behavioral control predictors to purchase housing (Phungwong, 2010; Numraktrakul et al., 2012). And some researcher found that perceived behavior control has no effect towards intention (Pavlou \& Chai, 2002; Ng \& Rahim, 2005; Yusliza \& Ramayah, 2011).

\subsubsection{Intention}

Intention is an indication of a person's willingness to perform the behavior, and it is an immediate antecedent of behavior. Intention is the dependent variable which is predicted by an independent variable namely attitude, Subjective Norm and Perceived Behavioral Control. Intention varies from time to time and as the time interval 
increases, the lower is the correlation between intention and action (Ajzen, 1991; Ajzen \& Fishbein, 1980; Han \& Kim, 2010). Davis et al. (1989) and Taylor and Todd (1995) found in their studies that intention is strong predictor of behavior. Therefore, the intention to purchase is an antecedent of a purchase decision (Phungwong, 2010). Figure 1 shows the relationship between independent and dependent variable which intention.

\subsection{Demographics}

Factor such as the demographics of a person can affect the intentions of a purchaser (Fishbein \& Ajzen, 1975). Speare et al. (1975) for example, states that demographic factors are driving housing preferences. Blackwell et. al. (1995) has identified internal and external factors influence purchasing behavior. While Gibler and Nelson (1998) discovered that, the demographic characteristics of the consumer also affect individuals' behavior. Furthermore, according to Nelson and Rabianski (1988), purchasing family housing is a function of psychographic and demographic variables. Demographic factors influence the behavior of purchasing a house. Thus, demographic characteristics such as Citizenship is a factor that influence the purchase-intention of a customer (Dawson et al., 1990; Yalch \& Spangenberg, 1990; Gattiker et al., 2000; Haddad et al., 2011).

Previous research shows that the demographic effect varies from study to study. Some studies that indicate that there is a significant impact of demographics on the behavior can be found in research by (Venkatesh et al., 2000; Morris et al., 2005), and other studies that found that there is no significant impact of demographics on the behavior are recorded in (Kotrlik et al., 2000; Kanbe, 2009). In France, for example, it was found that demographics influence French real estate purchasers (Violand \& Simon, 2007). Also, Al-Jurasiy (2008) found that demographics has effect on Saudi consumer purchase behavior. Figure 1 shows the moderating effect of demographics on the relationship between independent and dependent variable which intention.

These diverse findings concerning the role of demographics suggest an additional need for exploratory research in explaining the roles of citizenship related to intentions to purchase housing.

Theoretical framework:

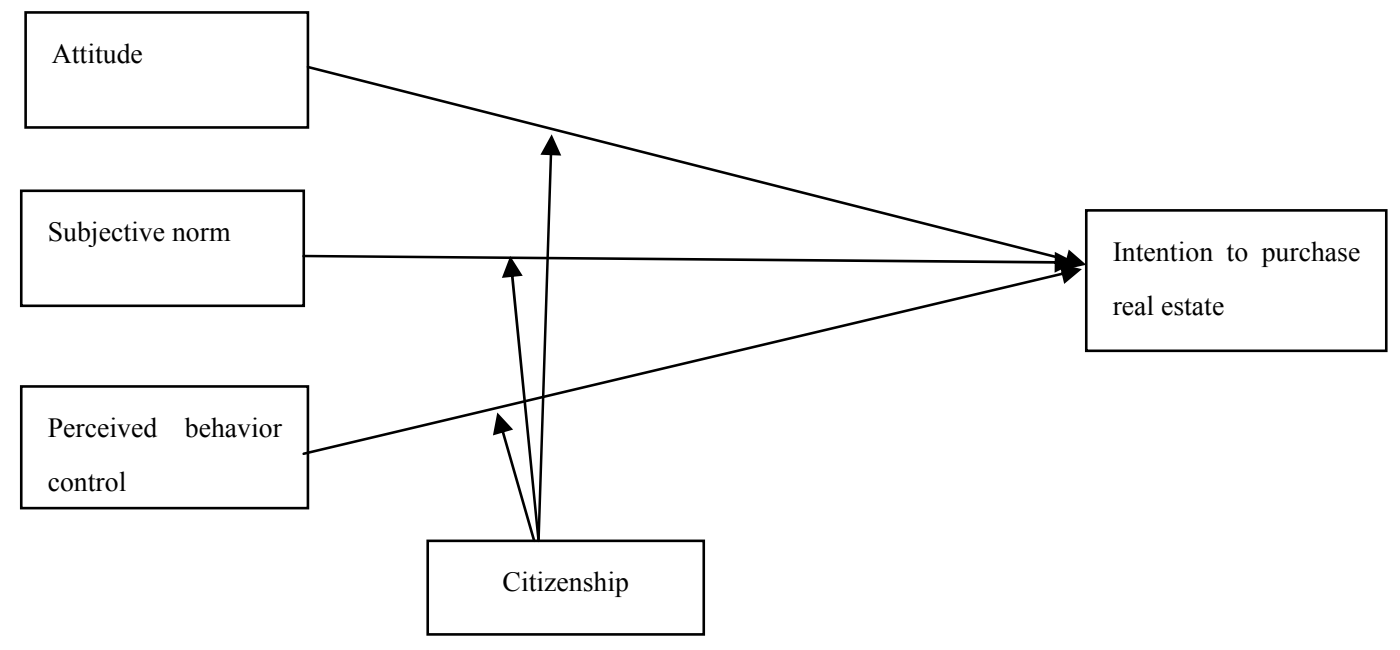

Figure 1. Effects of demographic (Citizenship) on the relationship between independent and dependent variable

\section{Research Methodology}

This study collected data through a survey distributed in Jeddah using a self-administrated questionnaire. The questions were adapted from various researches (Bredahl et al., 1999; Cook et al., 2000; Ajzen \& Fishbein's, 1980; Al-Nahdi, 2009; Davis et al., 1989; Gopi \& Ramayah, 2007; Jahya, 2004; Mills, 2006; Moor \& Benbasat, 1991; Norzalila, 2004; Numraktrakul et al., 2012; Ramayah et al., 2008; Rinner \& Heppleston, 2006; Al-Nahdi, 2011; Numraktrakul et al., 2012). The questionnaire consists of two main sections. The first section asks about the respondent's Demographics. The second asking about attitude, subjective norms, perceived behavior control. To assess attitude, subjective norms, perceived behavior control, the five-point Likert Scale was used (ranging from 1, Strongly disagree to 5, Strongly Agree, for Demographics the respondent was asked to tick the appropriate select. 


\subsection{Population and Data Collection}

Population for this study people living in Jeddah and who are above 18 years old. The sample was selected randomly. Where, Data collected by a questionnaire adapted from various researches. The questionnaire was distributed directly to respondents.

\subsection{Goodness of Measures}

Factor analysis and reliability were used to test the goodness of measures. Factor analysis is a test of how well an instrument measures the concept whereas reliability is a test of how consistently a measuring instrument measures the concept (Sekaran \& Bougie, 2010).

\subsection{Data Collection}

The questionnaire was distributed directly to respondents.

\subsection{Data Analysis Method}

In this study, the statistical tool SPSS version 21.0 (Statistical Package for Social Science) was applied to analyze the data profile and also the hypotheses testing. The following analysis was used: Descriptive Analysis was used to analyze the demographic information of respondents. As well as Goodness of Measure Analysis factor analysis and reliability analysis were conducted (Hair et al., 1998; Sekaran, 2003). This was to ensure that the data used to test the hypotheses are both valid and reliable. Factor Analysis was conducted based on Hair et al. (1998). The Varimax rotation method was also used. Kaiser-Meyer-Olkin (KMO) measure of sampling adequacy, Bartlett's test of sphericity, and anti-image correlation were used as well to verify the assumptions undertaken by the factor analysis. Cronbanch alpha was used to analyze the reliability of the instruments. Regression Analysis was used for hypothesis testing, it was used to investigate the relationship between the independent and dependent variables, and also the effect of moderating variables towards this relationship.

\subsection{Response Rate}

A total of 450 sets of questionnaires were distributed to respondents in Jeddah. Out of the total of questionnaires distributed, 380 sets of questionnaires were returned which represent $84 \%$. Only 322 sets of the questionnaires were usable which represents a rate of $71.5 \%$. Table 1 shows the responses to the distributed questionnaires.

Table 1. Distributions of questionnaires

\begin{tabular}{ll}
\hline Items & NO. \\
\hline Questionnaires distributed & 450 \\
Total response & 380 \\
Unusable response & 58 \\
Usable response & 322 \\
Total response rate & $84 \%$ \\
usable response rate & $71.5 \%$ \\
\hline
\end{tabular}

\section{Analyses and Results}

\subsection{Profile of Respondents}

The profile of respondent shows and as depicted in table 2 below, that respondents were aged between 18 to 25 representing 29.2 percent, and between 26-33 representing 24.8 percent, age between $34-40$ percent represents 24.8 percent. Respondents aged above 40 percent represent 24 percent of the total respondents. Respondents between 34-40 percent is aged between 26-33 years. 79.2 Percent of respondents are males, where as, 20.8 percent are females, around 64.6 percent of the respondents are married, and 35.4 percent are single. 17.4 Percent have only two family members, 34.5 percent have between 3-4 family members, 31.7 percent have 5-6 family members, and more than 6 family members represents 16.5 percent of respondents. 66.8 Percent of the respondents are Saudis, and 33.2 are Non-Saudis. Respondents educated to primary level represent 2.5 percent, where as 23.3 percent are secondary level, 4.3 percent are diploma level, 55.6 percent are Bachelor degree holders, whereas , 14 percent are post graduates, Professional qualification holders represent only 0.3 percent of the respondents. Of the study, 9 percent of the respondents are unemployed or retired, 23 percent own a business, 28 percent work in government, 32 percent work in the private sector, and others 8.1 percent work in different jobs. Respondents with income below SR 10,000 represent 47,5 percent of the study; 34,2 percent of the respondents income is between 10,001 to $20,000,14$ of the respondents income between 20,000 to 50,000 , and 4.3 percent of the respondents income is above SR50,001. 
Table 2. Profile of respondents

\begin{tabular}{|c|c|c|c|}
\hline Respondent's profile & Category & Frequency & Percentage \\
\hline \multirow{4}{*}{ Age (years) } & $18-25$ & 94 & 29.2 \\
\hline & $26-33$ & 80 & 24.8 \\
\hline & $34-40$ & 71 & 22 \\
\hline & Above 40 & 77 & 24 \\
\hline \multirow{2}{*}{ Gender } & Male & 255 & 79.2 \\
\hline & Female & 67 & 20.8 \\
\hline \multirow{2}{*}{ Marital status } & Single & 114 & 35.4 \\
\hline & Married & 208 & 64.6 \\
\hline \multirow{4}{*}{ Number of family members } & 2 & 56 & 17.4 \\
\hline & $3-4$ & 111 & 34.5 \\
\hline & $5-6$ & 102 & 31.7 \\
\hline & More than 6 & 53 & 16.5 \\
\hline \multirow{2}{*}{ Citizenship } & Saudi & 215 & 66.8 \\
\hline & Non-Saudi & 107 & 33.2 \\
\hline \multirow{6}{*}{ Education } & Primary level & 8 & 2.5 \\
\hline & Secondary level & 75 & 23.3 \\
\hline & Diploma & 14 & 4.3 \\
\hline & Bachelor & 179 & 55.6 \\
\hline & Post graduate & 45 & 14 \\
\hline & Professional qualifications & 1 & .3 \\
\hline \multirow{5}{*}{ Occupation } & Unemployed, Retired & 29 & 9 \\
\hline & Self-employed (own business) & 74 & 23 \\
\hline & Government employee & 90 & 28 \\
\hline & Private sector & 103 & 32 \\
\hline & others & 26 & 8.1 \\
\hline \multirow{4}{*}{ Monthly income } & Below SR 10,000 & 153 & 47.5 \\
\hline & SR 10,001 to 20,000 & 110 & 34.2 \\
\hline & SR 20,000 to 50,000 & 45 & 14 \\
\hline & above SR 50001 & 14 & 4.3 \\
\hline
\end{tabular}

\subsection{Factor Analysis}

Factor analysis was used to ensure that the number of items can be reduced to the number of concepts that were initially hypothesized (Hair et al., 1998). Minimum acceptable value for KMO is 0.50 with Bartlett's test of sphericity to be significant. Eigenvalue value should be 1 or greater. The cut off point for significant factor loading should be at least 0.50 on one factor.

Factor analysis was done on items of independent variables (Attitude, Subjective Norms and Perceived Behavioral Control). This examination revealed a combined total variance explanation of $64.33 \%$. The KMO measures of sampling adequacy stand at 0.814 . Table 3 summarizes factor loadings and cross factor loadings for independent variables that were extracted from the rotated component matrix. There we have attitude, Subjective norms and Perceived behavior control. 
Table 3. Factor loadings for independent variables

\begin{tabular}{|c|c|c|c|}
\hline \multirow[b]{2}{*}{ Factor 1:Attitude } & \multicolumn{3}{|c|}{ Components } \\
\hline & 1 & 2 & 3 \\
\hline Buying housing is a beneficial decision. & .851 & .157 & -.014 \\
\hline Buying housing is a good idea. & .845 & .171 & .009 \\
\hline Buying housing is a wise decision. & .856 & .171 & .002 \\
\hline Buying housing is an admired decision. & .781 & .207 & -.019 \\
\hline \multicolumn{4}{|l|}{ Factor 2:Subjective norms } \\
\hline My family thinks that I should buy housing. & .144 & .817 & -.011 \\
\hline My family would want me to buy housing. & .053 & .868 & .067 \\
\hline My family agrees with me to buy housing. & .246 & .829 & .026 \\
\hline My family thinks that buying housing is a wise decision. & .309 & .713 & -.003 \\
\hline \multicolumn{4}{|l|}{ Factor 3:Perceived behavior control } \\
\hline $\begin{array}{l}\text { I have enough opportunity (I have easy access to the market) in making a decision to buy } \\
\text { housing. }\end{array}$ & .082 & .004 & .785 \\
\hline I have enough time to make a decision to buy housing & .207 & -.105 & .653 \\
\hline I have enough money to buy housing. & -.078 & -.002 & .804 \\
\hline $\begin{array}{l}\text { I have enough skills and knowledge about housing to make my own decision. If I would like } \\
\text { to buy housing, }\end{array}$ & -.075 & .089 & .623 \\
\hline I have complete control over buying housing. & -.109 & .065 & .692 \\
\hline Eigenvalue & 4.051 & 2.566 & 1.746 \\
\hline Variance $(\%)$ & 31.16 & 19.73 & 13.43 \\
\hline Total variance & & 64.33 & \\
\hline Kaiser-Meyer-Olkin MSA KMO & & .814 & \\
\hline Bariett's test of sphericity & & 1755.75 & \\
\hline
\end{tabular}

Factor analysis was done on items of the dependent variable (Intention). Five questions were introduced to measure the dependent variable. This examination revealed a combined total variance explanation of $64 \%$. The KMO measures of sampling adequacy stand at .844 . Table 4 summarizes the factor loadings and cross factor loading which is shown at rotated component matrix.

Table 4. Factor loading for dependent variable intention to purchase real estate

\begin{tabular}{ll}
\hline Factor: Intention to purchase Real estate & Component \\
\hline I will continue to buy housing in the future. & .733 \\
I intend to buy housing frequently in the future. & .836 \\
I plan to buy housing. & .854 \\
I will try to buy housing. & .801 \\
I want to buy housing. & .784 \\
Eigenvalue & 3.220 \\
Variance (\%) & 64.396 \\
Total variance & 64.396 \\
Kaiser-Meyer-Olkin MSA KMO & .844 \\
Bariett's test of sphericity & 708.985 \\
\hline
\end{tabular}

\subsection{Reliability Analysis}

Reliability Analysis was conducted to ensure the consistency or stability of the items (Sekeran, 2003). The Cronbachs alpha test was used to analyze the reliability of the instrument. In this section all variables namely attitude, subjective norms and perceived behavior controls will be included in the reliability analysis. Table 5 shows the values of Cronbach's alpha for all the variables. 
Table 5. Reliability for independent and dependent variables

\begin{tabular}{llll}
\hline Variables & No. of items & No. of items retained & Cronbachs alpha \\
\hline Attitude & 4 & 4 & .879 \\
Subjective norms & 4 & 4 & .849 \\
Perceived behavior control & 5 & 5 & .756 \\
Intention & 5 & 5 & .859 \\
\hline
\end{tabular}

\subsection{Descriptive Analysis}

Descriptive analysis for independent variables (Attitude, Subjective Norms, Perceived Behavioral Control), and dependents (Intention) is presented in Table 6.

Table 6. Descriptive analysis

\begin{tabular}{lll}
\hline Variable & Mean & Std. Deviation \\
\hline Attitude & 4.1685 & .91060 \\
Subjective norms & 3.8230 & 1.02020 \\
Perceived behavior control & 2.8267 & .86721 \\
Intention & 3.6770 & .98223 \\
\hline
\end{tabular}

\subsection{Test of Hypotheses}

Hypothesis 1, 2, 3, and 4 predicted that the independent variables which include attitude, subjective norm, and perceived behavioral control are positively related to the dependent variable which is intention. Citizenship moderates the relationship between independents toward dependents. The Multiple regression analysis technique was used to test this relationship in this model. Two regression analyses were performed to determine the relationship between the independent variables and dependent variable and the effect of the moderator. Testing the interaction can show the moderator effect (Cohen \& Cohen, 1983). Moderation is like a variable that strengthens or weakens the relationship between the dependent and independent variables (Baron \& Kenny, 1986). Statistically moderation is an interaction between the independent variable and moderator, on the relationship towards dependent variable (Lee et al., 2008).

Firstly, multiple regression was conducted. It showed the following results $\mathrm{R}$ square $=31.8 \%$, this means that about $31.8 \%$ of the variation in the dependent variable can be explained by the independent variables jointly. $\mathrm{F}$ value $=49.37$, and $p=000<.01$ which is very significant, implying the model is adequate. The Durbin-Watson Test $\mathrm{D}=1.703$. More details can be found in table 7 .

Table 7. Multiple regression results between independent variables attitude, subjective norm, and perceived behavioral control with dependent variable intention dependent variable

\begin{tabular}{ll}
\hline Variable & Standardized Coefficients Beta \\
\hline Attitude & $0.278^{* * *}$ \\
Subjective norm & $0.388^{* * *}$ \\
Perceived behavioral control & 0.019 \\
$\mathrm{R}^{2}$ & 0.318 \\
Adjusted $\mathrm{R}^{2}$ & 0.311 \\
$\mathrm{~F}$ & 49.37 \\
Significant & 0.000 \\
Durbin-Watson Test & 1.703 \\
\hline
\end{tabular}

Note. ${ }^{*} \mathrm{p} \leq .05 * * \mathrm{p} \leq .01 * * * \mathrm{p} \leq .001$.

Secondly, Hierarchal regression was conducted. It shows the following results R square $=32.2 \%$ this means that about $32.2 \%$ of the variation and. $\mathrm{F}=000<.01$ which is very significant, implying the model is adequate. More details can be found in table 8 . 
Table 8. The effect of citizenship as a moderator

\begin{tabular}{llll}
\hline Selected variable & Model 1 (beta) & Model 2 (beta) & Model3 (beta) \\
\hline Attitude & $0.278^{* * *}$ & $0.278^{* * *}$ & $.280^{* * *}$ \\
Subjective norm & $0.388^{* * *}$ & $0.388^{* * *}$ & $.427^{* * *}$ \\
Perceived behavioral control & 0.019 & 0.020 & .006 \\
Citizenship & - & 0.006 & .102 \\
Citizenship with Attitude & - & - & .055 \\
Citizenship with subjective norm & - & - & -.269 \\
Citizenship with perceived behavioral control & - & - & .110 \\
R Square & 0.318 & 0.318 & 0.322 \\
Adjusted R Square & 0.311 & 0.309 & 0.307 \\
Sig. F & 000 & 000 & 000 \\
DurbinWatson index & 1.681 & &
\end{tabular}

Note. ${ }^{*} \mathrm{p} \leq .05 * * \mathrm{p} \leq .01 * * * \mathrm{p} \leq .001$.

$\mathrm{H} 1$ the more positive is attitude the greater is the consumer intention to purchase real estate.

Table 7 shows the results between attitude and intention to purchase real estate. Based on the results, attitude was significant ${ }^{* * *} \mathrm{p}<.00$ with Standardized Coefficients Beta $=0.278$ and have positive effect on Intention. Thus, H1 supported.

$\mathrm{H} 2$ the more positive is subjective norm the greater is the consumer intention to purchase real estate.

Table 7 shows the results of the degree of the effect of subjective norm toward intention to purchase real estate. Based on the results, subjective norm was significant $p<.00$ with Standardized Coefficients Beta $=0.388$ and have positive effect on intention to purchase real estate. Thus, $\mathrm{H} 2$ supported.

$\mathrm{H} 3$ the more positive is perceived behavioral control the greater is the consumer intention to purchase real estate.

Table 7 shows the results between perceived behavioral control and intention to purchase real estate. Based on the results, perceived behavioral control was not significant $p>.05$ with Standardized Coefficients Beta $=0.019$ and have no effect on Intention to purchase real estate. Thus, H3 not supported.

H4 Citizenship moderates independent variables (attitude, subjective norm, and perceived behavioral control) towards intention to purchase real estate.

Table 8 shows the results show the effect of Citizenship towards intention to purchase real estate. Based on the results, Citizenship was not significant $\mathrm{p}>.05$ and have no effect on Intention to purchase real estate. Thus, H4 not supported.

\section{Conclusion and Limitation}

\subsection{Conclusion}

The study has illustrated the ability of the TPB to explain the intention to purchase real estate, and whether Demographics namely Citizenship could also, moderate the relationship to purchase real estate. It was shown that the intention to purchase real estate was influenced by attitude and subjective norm while perceived behavioral control was not, with the subjective norm component being more influential. Citizenship was not a moderator on the relationship between independent and dependents.

This study provided what influence the behavior. The study has shown that attitude subjective norm are accepted for explaining behavior purchase of real estate in Saudi Arabia. In conclusion, it is assumed that the outcomes of this study have contributed some valuable information for researchers, customers, marketers and real estate owners. It is expected that the result of the survey will provide information on the intention to purchase real estate and which variables affect this intention. Therefore, as a result, this study can serve as a future reference on the study of real estate. Which will help consumer to know what influence them to make this behavior. Also, will help governments to set procedures and regulations for current and future plans.in addition this study will help real estate instructors to understand what influence consumers toward real estate and consider it at their marketing planning. Admittedly, there are some limitations which must be given due attention.

\subsection{Limitations}

Several limitations have been identified in this study. The results of this study couldn't provide a general picture of all customers in Saudi Arabia. Because this research was only conducted in Jeddah. Thus, the result obtained 
cannot accurately reflect the actual customers' intention to purchase real estate all over Saudi Arabia.

\section{Future Research}

Including different variable may explain more behavioral intention as Ajzen suggested (1991). Effect of income and in which point consumer decide and actually purchase housing. More research in many different states can be conduct to generalize the findings. In addition, if more characteristics of respondents' included in future research it may declare view to some motivators of purchasers.

\section{References}

Ajzen, I. (1991). The theory of planned behavior. Organizational Behavior and Human Decision Processes, 50, 179-211. http://dx.doi.org/10.1016/0749-5978(91)90020-T

Ajzen, I., \& Fishbein, M. (1980). Understanding attitudes and predicting social behavior. Englewood Cliffs, NJ: Prentice-Hall.

Alam, S. S., \& Sayuti, N. M. (2011). Applying the Theory of Planned Behavior (TPB) in halal food purchasing. International Journal of Commerce and Management, 21(1), 8-20. http://dx.doi.org/10.1108/10569211111111676

Al-Hathloul, S. A., \& Edadan, N. (1995). Urban development in Saudi Arabia: Challenges and opportunities. Riyadh, Saudi Arabia: Dar Al Sahan.

Al-Jeraisy, K. I. (2005). Consumer behavior: An analytical study of the Saudi family's purchase decisions. Riyadh: distributed by Al-Jeraisy Establishment.

Allen, J. D., Sorensen, G., Stoddard, A. M., Colditz, G., \& Peterson, K. (1998). Intention to Have a Mammogram in the Future Among Women Who Have Underused Mammography in the Past. Health Education \& Behavior, 25, 474-488. http://dx.doi.org/10.1177/109019819802500406

Al-Momani, A. H. (2000). Structuring information on residential building: a model of preference. Engineering, Construction and Architectural Management, 7(2), 179-190. http://dx.doi.org/10.1108/eb021143

Al-Nahdi, T. S. (2008). Factors influencing Malaysian Muslim to patronage halal restaurants-ambiance as a mediator. Business Review, 6(2), 121-133.

Al-Nahdi, T. S., Ismail, I., Haron, H., \& Islam, M. A. (2008). Intention to patronage halal restaurants among Malaysian Muslims? An issue of halal perception. Paper presented at the GSMI (First) Global Business Summit Conference, Kelantan, Malaysia.

Baker, E. W., Al-gahtani, S. S., \& Hubona, G. S. (2007). The effects of gender and age on new technology implementation in a developing country: Testing the theory of planned behavior (TPB). It \& People, 20(4), 352-375. http://dx.doi.org/10.1108/09593840710839798

Baron, R. M., \& Kenny, D. A. (1986). The Moderator-Mediator Variable Distinction in Social Psychological Research: Conceptual, Strategic, and Statistical Considerations. Journal of Personality and Social Psychology, 51(6), 1173-1182. http://dx.doi.org/10.1037/0022-3514.51.6.1173

Blackwell, R. D., Miniard, P. W., \& Engel, J. F. (2001). Consumer Behavior. Orlando, FL: Harcourt Inc.

Blanchard, C., Fisher, J., Sparling, P., Nehl, E., Rhodes, R., Courneya, K., \& Baker, F. (2008). Understanding Physical Activity Behavior in African American and Caucasian College Students: An Application of the Theory of Planned Behavior. Journal of American College Health, 56(4), 341-347.

Central Department of Statistics and Information. (2008). Central department of statistics and information, Saudi Arabia.

Chan, S., \& Lu, M. (2004). Understanding Internet Banking Adoption and Use Behavior: A Hong Kong Perspective. Journal of Global Information Management, 12(3), 21-43.

Cohen, J., \& Cohen, P. (1983). Applied Multiple Regression/Correlation Analysis for the Behavioral Science (2nd ed.). Hillsdale, NJ: Lawrence Erlbaum Associates.

Cronin, J. J., \& Taylor, S. A. (1992). Measuring Service Quality: A Re-Examination and Extension. Journal of Marketing, 56, 55-68.

Davis, F. D., Bagozzi, R. P., \& Warshaw, P. R. (1989). User Acceptance of Computer Technology: A Comparison of Two Theoretical Models. Management Science, 35, 982-1003. http://dx.doi.org/10.1287/mnsc.35.8.982 
Dawson, S., Bloch, P., \& Ridgway, N. (1990). Shopping motives, emotional states and retail outcomes. Journal of Retailing, 66, 408-427

Fang, M. I. (2006). Examining ethical intentions of individual employees of Taiwan from Theory of Planned Behavio. The Business Review, Cambridge, 6(1), 257-264.

French, D. P., Sutton, S., Hennings, S. J., Mitchell, J., Wareham, N. J., Griffin, S., . . Kinmonth, A. L. (2005). The Importance of Affective Beliefs and Attitudes in the Theory of Planned Behavior: Predicting Intention to Increase Physical Activity1. Journal of Applied Social Psychology, 35(9), 1824-1848. http://dx.doi.org/10.1111/j.1559-1816.2005.tb02197.x

Fu, J., Farn, C., \& Chao, W. (2006). Acceptance of electronic tax filing: A study of taxpayer intentions. Information \& Management, 43, 109-126. http://dx.doi.org/10.1016/j.im.2005.04.001

Gattiker, U. E., Perlusz, S., \& Bohmann, K. (2000). Using the Internet for B2B activities: A review and future directions for research. Internet Research, 10, 126-140. http://dx.doi.org/10.1108/10662240010322911

Gibler, K. M., \& Nelson, S. L. (2003). Consumer Behavior Applications to Real Estate Education. Journal of Real Estate Practice and Education, 6(1), 63-89.

Godin, G., Gagné, C., Maziade, J., Moreault, L., Beaulieu, D., \& Morel, S. (2001). Breast cancer: The intention to have a mammography and a clinical breast examination-application of the theory of planned behavior. Psychology \& Health, 16, 423-441. http://dx.doi.org/10.1080/08870440108405517

Gopi, M., \& Ramayah, T. (2007). Applicability of theory of planned behavior in predicting intention to trade online: Some evidence from a developing country. International Journal of Emerging Markets, 2(4), 348-360. http://dx.doi.org/10.1108/17468800710824509

Gupta, S., \& Ogden, D. T. (2009). To buy or not to buy? A social dilemma perspective on green buying. Journal of Consumer Marketing, 26(6), 376-391. http://dx.doi.org/10.1108/07363760910988201

Haddad, M., Judeh, M., \& Haddad, S. (2011). Factors Affecting Buying Behavior of an Apartment an Empirical Investigation in Amman, Jordan. Journal of Applied Sciences, Engineering and Technology, 3(3), 234-239.

Hair, J. F., Anderson, R. E., Tatham, R. L., \& Black, W. C. (1998). Multvariate data analysis (5th ed.). New Jersey: New Jersey.

Han, H., \& Kim, Y. (2010). An investigation of green hotel customers? decision formation: Developing an extended model of the theory of planned behavior. International Journal of Hospitality Management, 29(4), 659-668. http://dx.doi.org/10.1016/j.ijhm.2010.01.001

Han, H., \& Sheu, C. (2010). Application of the Theory of Planned Behavior to green hotel choice: Testing the effect of environmental friendly activities. Tourism Management, 31(1), 325-334. http://dx.doi.org/10.1016/j.tourman.2009.03.013

Iakovleva, T., Kolvereid, L., \& Stephan, U. (2011). Entrepreneurial intentions in developing and developed countries. Education + Training, 53(5), 353-370. http://dx.doi.org/10.1108/00400911111147686

Jabareen, Y. (2005). Culture and Housing Preferences in a Developing City. Environment and Behavior, 37(1), 134-146. http://dx.doi.org/10.1177/0013916504267640

Jahya, N. B. (2004). Factors That Influence Muslim Consumers Preference Towards Islamic Banking Products or Facilities: Theory of Reasoned Action (Unpublished master's thesis). universiti sains malaysia, Pinang, Malaysia.

Jaradat, M. R., \& Rababaa, M. S. (2013). Assessing Key Factor that Influence on the Acceptance of Mobile Commerce Based on Modified UTAUT. International Journal of Business and Management, 8(23), 102-112. http://dx.doi.org/10.5539/ijbm.v8n23p102

Jr., W. L., Agarwal, R., \& Sambamurthy, V. (2003). Sources of Influence on Beliefs about Information Technolgoy Use: An Empirical Study of Knowledge Workers. Management Information Systems Quarterly, 27(4), 657-678.

Kalafatis, S. P., Tsogas, M. H., \& Blankson, C. (2000). Positioning strategies in business markets. Journal of Business \& Industrial Marketing, 15(6), 416-37. http://dx.doi.org/10.1108/08858620010349501

Kichen, J. M., \& Roche, J. L. (1990). Life-care resident preferences. In R. D. Chellis \& P. J. Grayson (Eds.), Life care: A long-term solution? (pp. 49-60). Lexington: MA Lexington. 
Kim, Y., \& Han, H. (2010). Intention to pay conventional-hotel prices at a green hotel? A modification of the theory of planned behavior. Journal of Sustainable Tourism, 18(8), 997-1014. http://dx.doi.org/10.1080/09669582.2010.490300

Knabe, A. (2012). Applying Ajzen's theory of planned behavior to a study of online course adoption in public relations education. Milwaukee.

Kokliÿc, M. K., \& Vida, I. (2009). A Strategic Household Purchase: Consumer House Buying Behavior. Managing Global Transitions, 7(1), 75-96.

Kotrlik, J. W., Redmann, D. H., Harrison, B. C., \& Handley, C. S. (2000). Information Technology Related Professional Development Needs Of Louisiana Agriscience Teachers.

Lechner, L., Vries, H. D., \& Offermans, N. (1997). Participation in a Breast Cancer Screening Program: Influence of Past Behavior and Determinants on Future Screening Participation. Preventive Medicine, 26, 473-482. http://dx.doi.org/10.1006/pmed.1997.0161

Lee, S., Taylor, P. D., \& Hong, S. (2008). Moderating effect of forest cover on the effect of proximity to chemical facilities on property values. Landscape and Urban Planning, 82(2), 171-176. http://dx.doi.org/10.1016/j.landurbplan.2008.02.002

Lonappan, J. (2013). An Evaluation of factors influencing customer? home buying decision. Indian Journal of Research, 2(11).

Lutfi. (2010). Relationship between demographic factors and Investment Decision in Surabaya. Journal of Economics, Business and Accountancy Ventura, 13(3), 213-224. Retrieved from Accreditation No. 110/DIKTI/Kep/2009.

Malhotra, Y., \& Galletta, D. F. (1999). Extending the Technology Acceptance Model to Account for Social Influence: Theoretical Bases and Empirical Validation. Theoretical Bases and Empirical Validation. Proceedings of the 32nd Hawaii International Conference on System Sciences. http://dx.doi.org/10.1109/HICSS.1999.772658

Mathieson, K. (1991). Predicting User Intentions: Comparing the Technology Acceptance Model with the Theory of Planned Behavior. Information Systems Research, 2(3), 173-191. http://dx.doi.org/10.1287/isre.2.3.173

Mubarak, F. A. (1999). Cultural Adaptation to Housing Needs: A Case Study, Riyadh, Saudi Arabia. IAHS Conference Proceedings. San Francisco.

Nelson, T., \& Rabianski, J. (1988). Consumer Preferences in Housing Market Analysis: An Application of Multidimensional Scaling Techniques. Real Estate Economics, 16(2), 138-159. http://dx.doi.org/10.1111/1540-6229.00451.

Ng, B., \& Rahim, M. (2005). A socio-behavioral study of home computer users' intention to practice security. PACIS 2005 Proceedings.

Norzalila, B. J. (2004). A study of Consumer Intention to Purchase Halal Food Products (Doctoral dissertation). Universiti Sains Malaysia, Pinang, Malaysia.

Numraktrakul, P., Ngarmyarn, A., \& Panichpathom, S. (2012). Factors Affecting Green Housing Purchase. In 17th International Business Research Conference. Toronto, Canada.

Nysveen, H., Pedersen, H., Thorbjornsen, H., \& Berthon, P. (2005). Mobilizing the Brand: The Effects of Mobile Services on Brand Relationships and Main Channel Use. Journal of Service Research, 7(3), 257-276. http://dx.doi.org/10.1177/1094670504271151

Opoku, R. A., \& Abdul-Muhmin, A. G. (2010). Housing preferences and attribute importance among low-income consumers in Saudi Arabia. Habitat International, 34, 219-227. http://dx.doi.org/10.1016/j.habitatint.2009.09.006

ORJI, R. (2010). Impact of Gender and Nationality on Acceptance of a Digital Library: An Empirical Validation of Nationality Based UTAUT Using SEM. Journal of Emerging Trends in Computing and Information Sciences, 1(2), 68-79.

Otaibi, A. (2006). The Aspiration for Housing in Jeddah-Saudi Arabia. Forum, 6(1).

Pavlou, P. A., \& Chai, L. (2002). What Drives Electronic Commerce across Cultures? Across-Cultural Empirical Investigation of the Theory of Planned Behavior. Journal of Electronic Commerce Research, 3(4), 240-253. 
Phungwong, O. (2010). Factors influencing home purchase intention of Thai single people (Doctoral dissertation, International graduate school of business, University of South Australia, Adelaide, Australia).

Priyambodo, L., Tjiptono, F., \& Suyoto. (2012). M-Commerce in Indonesia: Problems and Prospects. International Journal of Computer Applications \& Information Technology, 1(2), 71-76.

Ramayah, T., \& Suki, N. M. (2006). Intention to use mobile PC among MBA students: Implications for technology integration in the learning curriculum. UNITAR E-Journal, 1(2), 1-10.

Ramayah, T., Jantan, M., \& Aafaqi, B. (2003). Internet usage among students of Institutions of higher learning: The role of motivational variables. The Proceedings of the 1st International Conference on Asian Academy of Applied Business Conference, Sabah, Malaysia, 10-12th July, 2003.

Ramayah, T., May, O. S., \& Omar, A. (2008). Behavioral determinants of online banking adoption: Some evidence from a multicultural society? Journal of Management, 2(3), 29-37.

Rinner, C., \& Heppleston, H. (2006). The spatial dimensions of multi criteria evaluation case study of a home buyer?s spatial decision support system. In Geographic Information Science (pp. 338-352). Springer Berlin Heidelberg.

Rivis, A., \& Sheeran, P. (2003). Descriptive norms as an additional predictor in the theory of planned behaviour: A meta-analysis: Developmental, Learning, Personality, Social. Current Psychology, 22, 218-233. http://dx.doi.org/10.1007/s12144-003-1018-2

Rossini, P. (1998). Assessing Buyer Search Behaviour for Residential House Purchasers in Adelaide. School of International Business, University of South Australia.

Rutter, D. R. (2000). Attendance and re-attendance for breast cancer screening: A prospective 3-year test of the Theory of Planned Behavior. British Journal of Health Psychology, 5, 1-13. http://dx.doi.org/10.1348/135910700168720

Sekaran, U. (2003). Research methods for business: A skill-building approach (4th ed.). New York: John Wiley \& Sons, Inc

Sekaran, U., \& Bougie, R. (2010). Research methods for business: A skill-building approach. London: Wiley.

Shih, Y., \& Fang, K. (2004). The use of a decomposed theory of planned behavior to study Internet banking in Taiwan. Internet Research, 14(3), 213-223. http://dx.doi.org/10.1108/10662240410542643

Speare, A., Goldstein, S., \& Frey, W. H. (1975). Residential mobility, migration, and metropolitan change. Cambridge, MA: Ballinger Pub. Co.

Summers, T. A., Belleau, B. D., \& Xu, Y. (2006). Predicting purchase intention of a controversial luxury apparel product. Journal of Fashion Marketing and Management, 10(4), 405-419. http://dx.doi.org/10.1108/13612020610701947

Susilawati, C., \& Anunu, F. B. (2001). Motivation and Perception Factors Influence Buying Home Behavior in Dilly, East Timor. Proceedings of the 7th Pacific Rim Real Estate Society Annual Conference, 1-77.

Taylor, S., \& Todd, P. A. (1995). Understanding Information Technology Usage: A Test of Competing Models. Information Systems Research, 6(2), 144-176. http://dx.doi.org/10.1287/isre.6.2.144

Tella, A. (2011). Predicting Users? Acceptance of E-Library from the Perspective of Technology Acceptance Model. International Journal of Digital Library Systems, 2(4), 34-44.

Teo, T. S., \& Pok, S. H. (2003). Adoption of WAP-enabled mobile phones among Internet users. Omega-International Journal of Management Science, 31, 483-498. http://dx.doi.org/10.1016/j.omega.2003.08.005

Teo, T., \& Lee, C. B. (2010). Explaining the intention to use technology among student teachers: An application of the Theory of Planned Behavior (TPB). Campus-wide Information Systems, 27(2), 60-67. http://dx.doi.org/10.1108/10650741011033035

Thakur, R., \& Srivastava, M. (n.d.). Customer usage intention of mobile commerce in India: an empirical stud. Journal of Indian Business Research, 5(1), 52-72.

Tonglet, M., Phillips, P. S., \& Read, A. D. (2004). Using the Theory of Planned Behavior to investigate the determinants of recycling behavior: A case study from Brixworth, UK. Resources Conservation and Recycling, 41(3), 191-214. http://dx.doi.org/10.1016/j.resconrec.2003.11.001 
Vaile, M. S., Calnan, M., Rutter, D. R., \& Wall, B. (n.d.). Breast cancer screening services in three areas: Uptake and satisfaction. Journal of Public Health Medicine, 15, 37-45.

Venkatesh, V., \& Davis, F. D. (2000). A Theoretical Extension of the Technology Acceptance Model: Four Longitudinal Field Studies.

Venkatesh, V., Morris, M. G., Davis, G. B., \& Davis, F. D. (2003). User Acceptance of Information Technology: Toward a Unified View. Management Information Systems Quarterly, 27(3), 425-478.

Violand, W., \& Simon, A. (2011). Real estate brokers: Do they inflate housing prices? The case of France.

Wise, D. K., Goggin, M., Metcalf, K., \& Kennedy, S. (2006). Predicting intentions to use condoms using gender, sexual experience, and the Theory of Planned Behavior. American Journal of Health Education, 37(4), 210-219.

Wu, I., \& Chen, J. (2005). An extension of Trust and TAM model with TPB in the initial adoption of on-line tax: An empirical study. International Journal of Human-computer Studies / International Journal of Man-Machine Studies, 62(6), 784-808. http://dx.doi.org/10.1016/j.ijhcs.2005.03.003

Wu, S., Lin, C. S., \& Lin, J. (2011). An empirical investigation of online users' keyword ads search behaviors. Online Information Review, 35(2), 177-193. http://dx.doi.org/10.1108/14684521111127998

Yalch, R., \& Spangenberg, E. (1990). Effects of Store Music on Shopping Behavior. Journal of Consumer Marketing, 7(2), 55-63. http://dx.doi.org/10.1108/EUM0000000002577

Yusliza, M. Y., \& Ramayah, T. (2011). Explaining the Intention to Use Electronic HRM among HR Professionals: Results from a Pilot Study. Australian Journal of Basic and Applied Sciences, 5(8), 489-497.

\section{Copyrights}

Copyright for this article is retained by the author(s), with first publication rights granted to the journal.

This is an open-access article distributed under the terms and conditions of the Creative Commons Attribution license (http://creativecommons.org/licenses/by/3.0/). 